\title{
TEKNIK BUDIDAYA TANAMAN SAWI HIJAU (Brassica Juncea L)
}

\author{
Mahrus Ali, waka Kogoya, Yeni Ika Pratiwi \\ Fakultas Pertanian Program Studi Agroteknologi \\ Universitas Merdeka Surabaya \\ Email: sengkomahrus@gmail.com
}

\begin{abstract}
ABSTRAK
Dalam dunia pertanian hasil panen yang melimpah sangat diinginkan bagi para pembudidaya, oleh sebab itu berbagai cara budidaya yang baik dan dapat menghasilkan hasil yang baik terus diterapkan. Baik tanaman sayuran, tanaman pangan dan tanaman perkebunan.Teknik Budidaya Sawi Hijau meliputi beberapa perlakuan diantaranya Pembenihan, Pengolahan Tanah, Penyemaian, Penanaman, Transplanting, Penyiraman, Pengendalian Hama dan Penyakit, Pemupukan dan panen. Budidaya Tanaman Sawi tidak jauh beda dengan budidaya tanaman sayuran lainya. Hanya yang perlu diperhatikan pada tanaman sawi pada semua proses pada pengendalian Hama dan penyakit karena begitu tanaman sawi terserang hama dan penyakit maka tanaman sawi akan rusak dan tidak bisa dikonsumsi atau dijual dipasaran.
\end{abstract}

Kata Kunci: Tanama Sawi Hijau, Teknik Budidaya Sawi Hijau,

\section{PENDAHULUAN}

Tanaman sayuran seperti sawi (Brassica juncea) ini Di Indonesia baik dibudidaya pada tempat yang berdataran tinggi maupun di dataran rendah baik itu musim dingin atau musim kemarau, tetapi paling baik tanaman sawi dibudidayakan pada dataran tinggi dengan ketinggian 5 meter sampai dengan 1.200 meter dpl. Namun biasanya dibudidayakan pada daerah yang mempunyai ketinggian 100 meter sampai 500 meter dpl dan tanah yang baik untuk budidaya tanaman sawi adalah tanah yang memiliki tekstur tanah yang gembur, banyak mengandung humus, subur, serta pembuangan airnya baik (Hariyadi, Ali, \& Nurlina, 2017). Derajat kemasaman (pH) tanah yang optimum untuk pertumbuhannya adalah antara $\mathrm{pH}$ 6-7. Tanaman sawi ini selain dapat ditanam pada areal persawahan yang luas juga dapat dibudidayakan pada areal yang yang sempit dengan menggunakan pot atau polybag.

Tanaman sawi memiliki perawatan yang tidak begitu sulit dan pertumbuhan tanaman cepat, sehingga budidaya tanaman sayuran seperti sawi ini sering diterapkan oleh para petani untuk mendapatkan hasil yang cepat. Pada perawatan tanaman sawi hijauhal yang biasa dilakukan adalah penyiangan tanaman, pemupukan dan 
penyemprotan. Dalam pemeliharaan tanaman ini harus dilakukan dengan teratur yang dapat mencegah adanya hama atau penyakit yang tidak diinginkan. Pada tanaman sawi ini hama yang sering menyerang adalah ulat dan belalang sedangkan penyakit yang sering menyerang adalah penyakit layu, jamur dan plasmolisis yang disebabkan karena cara pemupukan yang salah atau kebanyakan dalam pemberian pupuk (Ali, 2015). Oleh sebab itu, cara budidaya tanaman sawi dan percobaan berbagai macam media dilakukan agar bisa mendapatkan hasil yang maksimal. Manfaat sawi hijau sangat baik untuk menghilangkan rasa gatal di tenggorokan pada penderita batuk, penyembuh penyakit kepala, bahan pembersih darah, memperbaiki fungsi ginjal, serta memperbaiki dan memperlancar pencernaan.

Sendangkan kandungan yang terdapat pada sawi hijau adalah protein, lemak, karbohidrat, Ca, P, Fe, Vitamin A, Vitamin B, dan Vitamin C. Sayur sawi hijau biasanya berupa tumisan dengan berbagai sajuran lain Berbagai jenis olahan makanan yang dijual, biasanya lebih memilih sawi hijau ketimbang berbagai jenis sayuran lain. Hal ini karena sawi hijau memiliki rasa khas enak yang tetap nikmat kalau dicampur dengan berbagai macam makanan. Selain itu, bagi yang menyukai sawi hijau terdapat banyak sekali keuntungan yang akan dipeoleh dari manfaat kandungan gizinya. berikut ini beberapa manfaat sawi hijau untuk kesehatan tumbuh:

Asupan rendah vitamin $\mathrm{K}$ telah dikaitkan dengan resiko yang lebih tinggi karena patah tulang. mengkonsumsi vitamin $\mathrm{K}$ adalah hal penting untuk kesehatan yang baik, karena bertindak sebagai pengubah protein matriks tulang, meningkatkan penyerapan kalsium dan dapat mengurangi ekskresi kalsium. Satu cangkir rebus sawi hijau memberikan 770 mikrogram vitamin K, yaitu lebih dari 100\% dari kebutuhan harian yang direkomendasikan.

RincianGiziSawiHijau.

Menurut ( Haryanto.2007) Satu cangkir sawi hijau mengandung :

\begin{tabular}{|l|c|}
\hline Kalori & 63 \\
\hline Gram protein & 5 \\
\hline Gram lemak & 1 \\
\hline $\begin{array}{l}\text { Gram karbohidrat (termasuk 8 gram serat dan 1 } \\
\text { gram gula ) }\end{array}$ & $25 \%$ \\
\hline Dari kebutuhan harian untuk vitamin A & $5 \%$ \\
\hline Dari kebutuhan harian untuk vitamin C & 11 \\
\hline
\end{tabular}




\begin{tabular}{|l|l|}
\hline Dari kebutuhan kalium & 26 \\
\hline Zat besi & $12 \%$ \\
\hline Dari kedua vitamin B-6 magnesiumm & $10 \%$ \\
\hline
\end{tabular}

Selain itu, sawi hijau merupakan sumber yang sangat kaya vitamin $\mathrm{K}$ dan juga mengandung folat, thiamin, niacin, asam pantotenat, cloline, fosfor dan kalium.

\section{TEKNIK BUDIDAYA SAWI HIIAU}

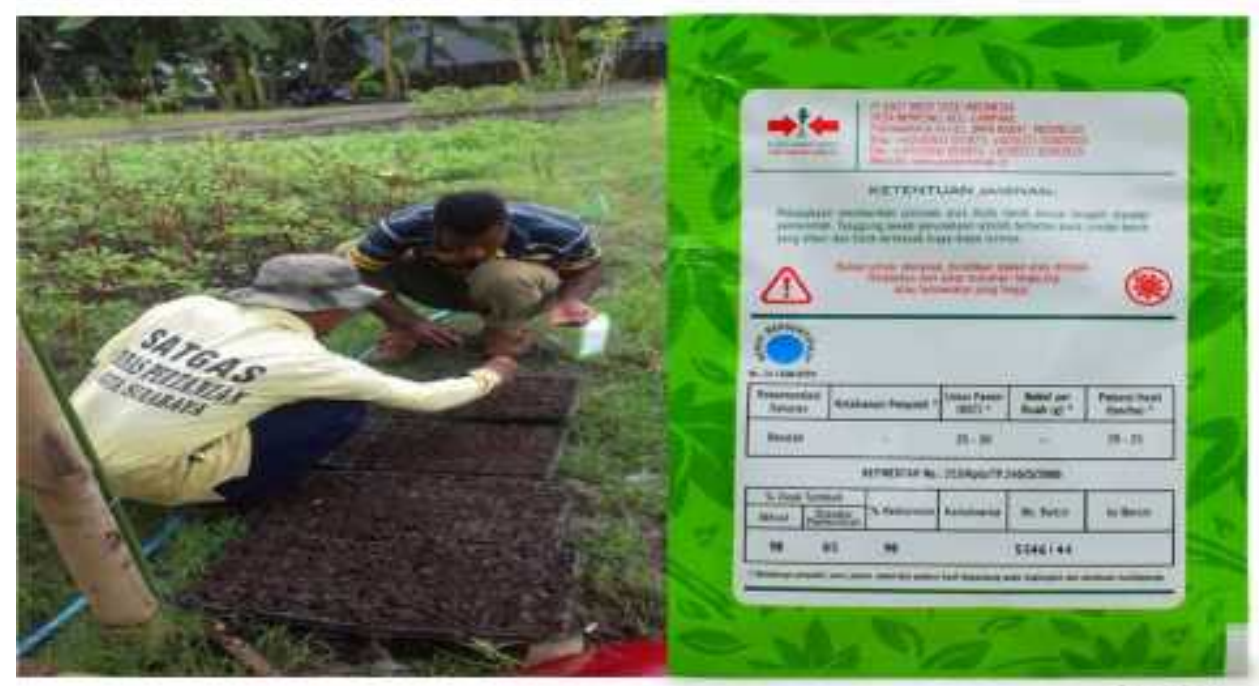

Gambar 1. Pembenihan

\section{Pembenihan}

Satu faktor penentu keberhasilan budidaya sawi hijau adalah faktor pembenihan, karena benih yang baik dapat menghasilkan tanaman yang memiliki pertumbuhan bagus. Pada umumnya benih sawi yang baik memiliki bentuk bulat, kecil, warna kulit coklat kehitaman, agak keras, dan permukaannya licin mengkilap. Benih sawi yang akan digunakan untuk bercocok tanam harus memiliki kualitas yang baik. Jika benih tersebut membeli di toko, maka saat membeli harus diperhatikan lamanya penyimpanan, kadar air, varietas, suhu dan tempat untuk menyimpan.Persemaian yang digunakan melalui bahan treas, lebar 25 meter, panjang 1 meter, benih di tebar di treas dan tutupi benih tersebut dengan tanah halus setebal 1-2 cm perbandingan tanah dan pupuk organik 2-2 pembenihan dilakukan selama 1 hari. 


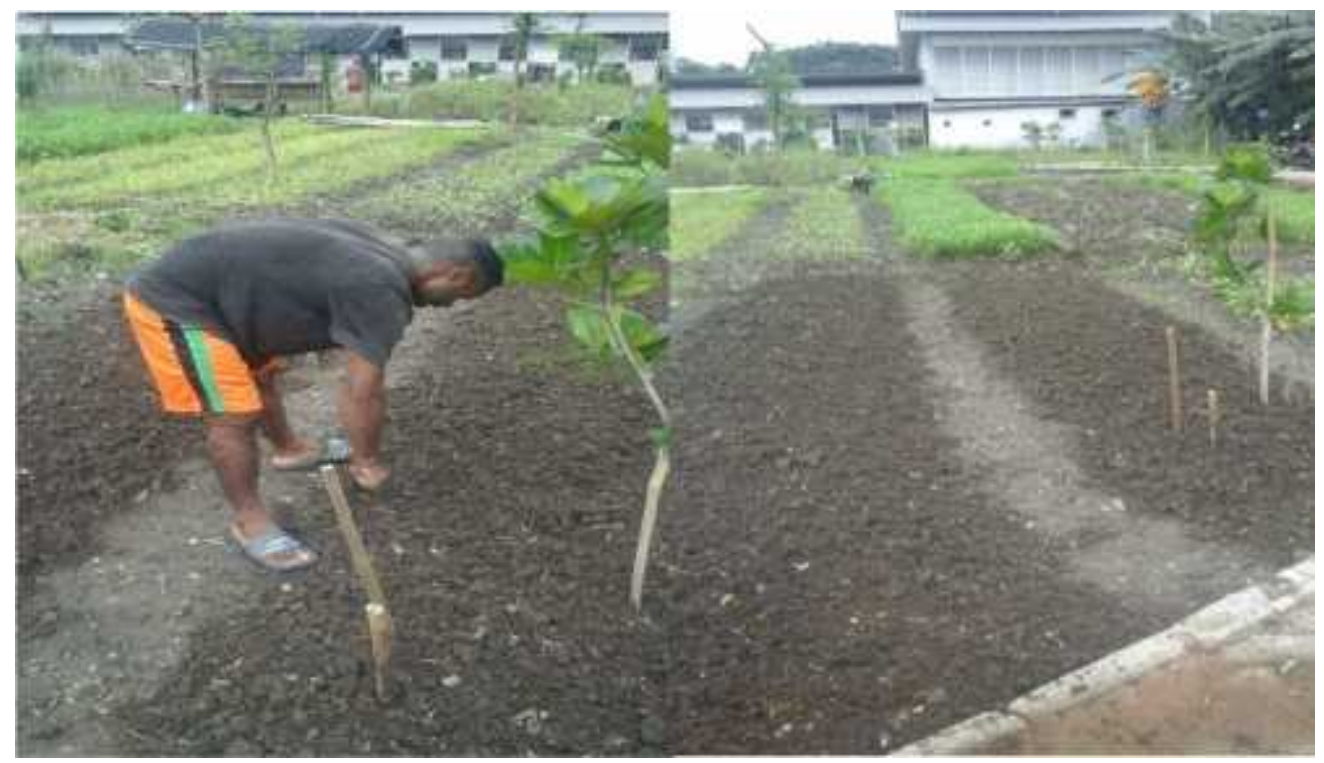

Gambar 2. Pengolahan Tanah

\section{Pengolahan Tanah}

Pengolahan tanah secara umum proses pengolahan tanah untuk budidaya sawi hijau yang dimaksud adalah melakukan penggemburan tanah di gambus ukuran $20 \mathrm{~cm}$-.Pemberian pupuk dasar pada tanah yang tujuannya untuk menambah kesuburan pada tanaman. Maka diberi pupuk organik, seperti pupuk kandang atau kompos jerami sebanyak $200 \mathrm{~kg}$ diberikan saat berlangsungnya penggemburan tanah.Agar pupuk organik tersebut dapat cepat merata dan bercampur dengan tanah yang akan digunakan, maka digunakan perbandingan antara pupuk organik dan tanah sebesar 2:2.

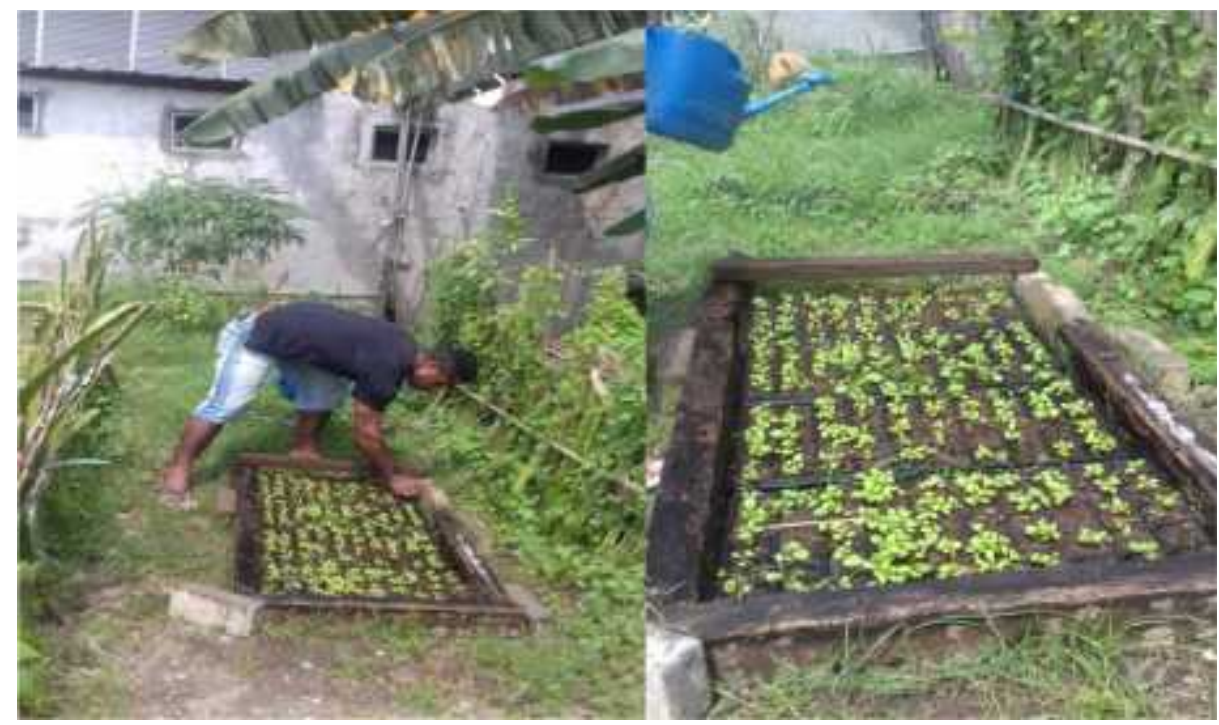

Gambar 3. Penyemaian 


\section{Penyemaian}

Menebarkan pupuk kandang ditambah tanah dengan perbandingan 2:2. dimasukan di treas isi didalam treas lebar 25 meter, panjang 1 meter. Benih dan tutupi benih tersebut dengan tanah halus setebal 1-2 $\mathrm{cm}$. Pecah lembaga kurang lebih 8 hari, penyemaian dilakukan selama 2 minggu.

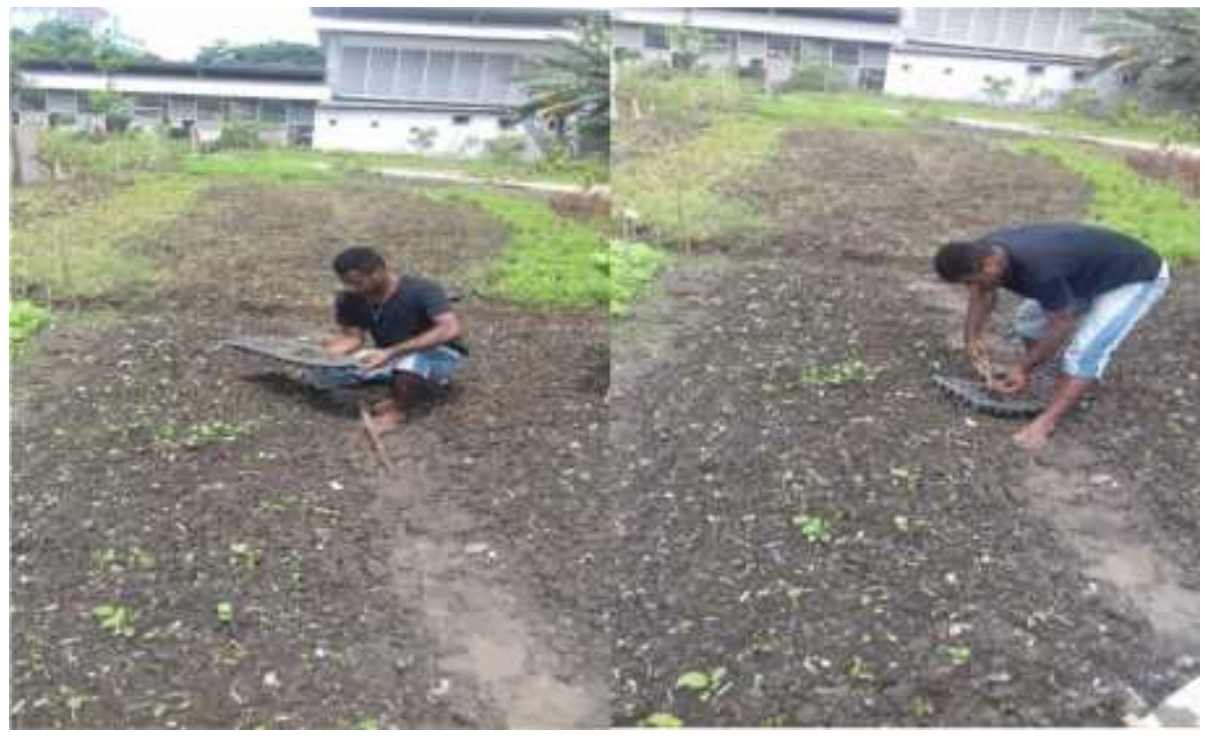

Gambar 5. Penanaman

\section{Penanaman}

Penanaman yang dilakukan dengan cara transplanting mencabut bibit dari tempat persemaian dan dilakukan penanaman secara langsung di Treas 30-30. dipilih terlebih dahulu bibit yang baik, bibit dipindahkan ke polybag. 1 polybag untuk 1 tanaman, Untuk jarak tanam polybag adalah $25 \times 25 \mathrm{~cm}$. penanaman dilakukan halaman belakang dinas pertanian.

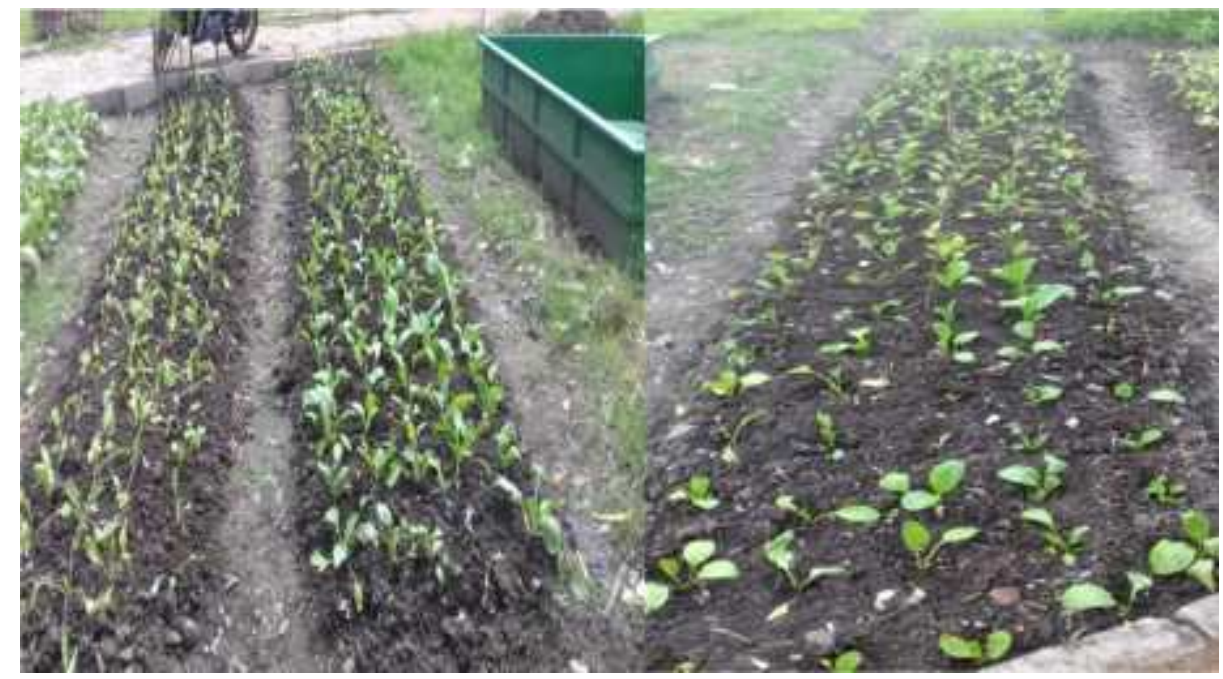

Gambar 4. Transplanting 


\section{Transplanting}

Transplanting dilakukan dengan bertumbuh semaksimal dan mengisi sawi pada media Tanah hingga penuh kemudian dibasahi dengan air. Jika benih sudah berdaun 2-3 helai, tanaman sawi sudah dapat dipindah ke Tanah panel semai. Untuk setiap satu lubang tanaman, isi dengan satu benih dan jangan lebih.

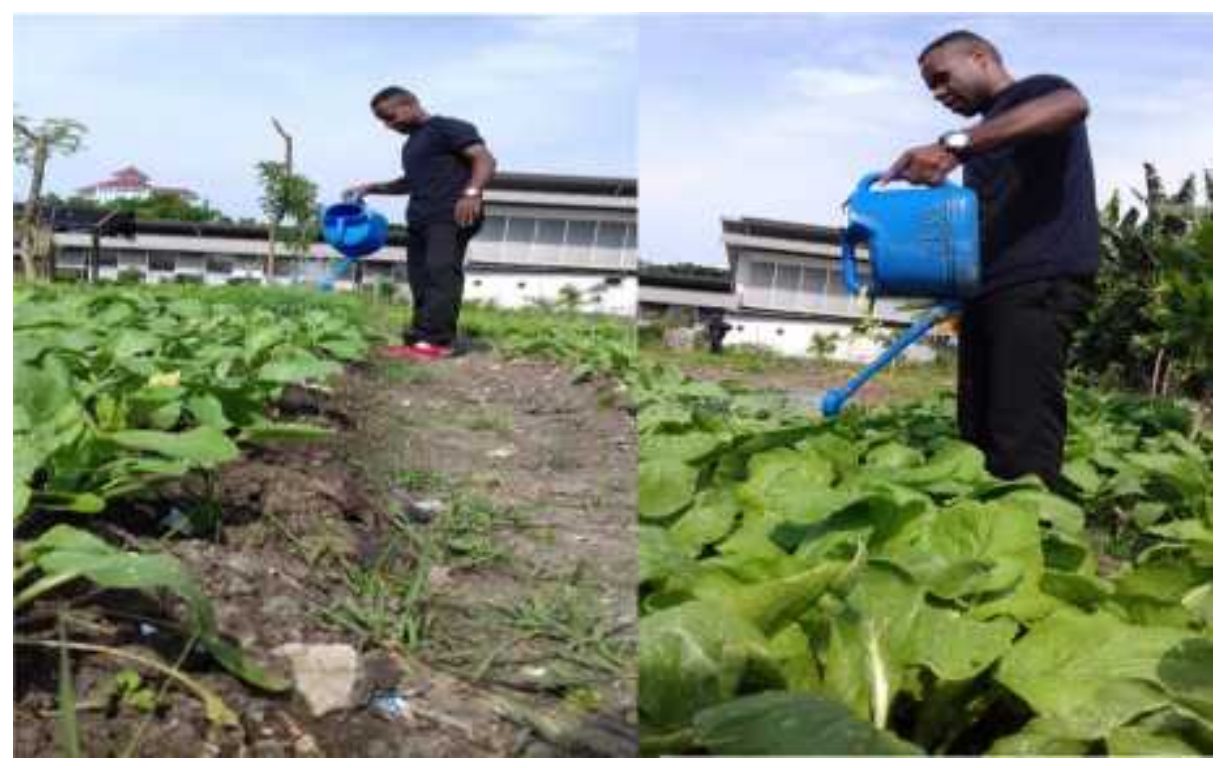

Gambar 6. Penyiraman

\section{Penyiraman}

Pertama yang harus diperhatikan dalam perawatan adalah penyiraman. Penyiraman tergantung pada musim. Jika musim penghujan datang dan curah hujan berlebihan, maka pengurangan air harus dilakukan. Tetapi jika sebaliknya, yakni jika air kurang karena datangnya musim kemarau, maka harus dilakukan penambahan air, agar kecukupan bagi tanaman sawi Senantiasa terpenuhi jika tidak terlalu panas, Penyiraman dilakukan sehari sekali pada pagi hari dan sore hari awal tanam sampai panen.sedangkan jika cuaca tidak terlalu kering penyiraman dapat itu dapat melakukan yang baik dan segar

\section{Pengendalian Hama dan Penyakit}

Pengendalian hama dan penyakit secara manual yang dilakukan dengan cara yaitu membunuh hama secara langsung dan mencabut tanaman yang terserang penyakit. Pada saat dilakukan pkl tidak terdapat hama dan penyakit

\section{Pemupukan}

Sebelum menanam sudah diberi pupuk (urea kandang, kompos,), tanah maka itu pada saat pertumbuhan tanaman tidak memberi pupuk lagi karena mengandung unsur nitrogen $(\mathrm{N})$ organik. 


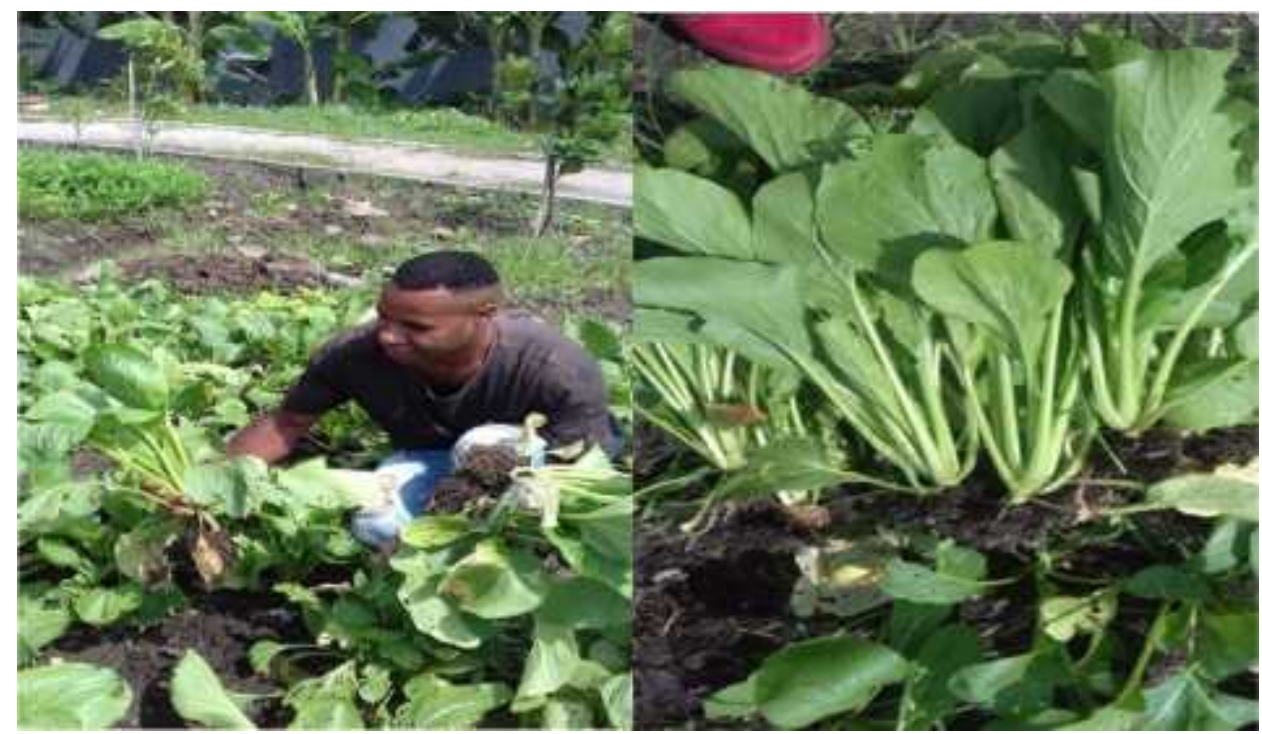

Gambar 7. Panen

\section{Panen}

Panen ada 2 cara yaitu mencabut seluruh tanaman beserta akarnya dengan memotong bagian pangkal batang yang berada di atas tanah. Pada Umur 30-40 hari dari umur semai, tanaman sawi sudah dapat dipanen. Untuk tanaman yang pertumbuhannya baik, disetiap polybag dapat menghasilkan sawi hijau, beratnya $175 \mathrm{gm}$.

\section{PEMBAHASAN}

Benih yang digunakan sebagai bahan tanaman diperoleh dari toko yang telah dipersiapkan persemaian yang digunakan melalui bahan treas, lebar 25 meter, panjang 1 meter tebar benih dan tutupi benih tersebut dengan tanah halus setebal 1-2 cm, perbandingan tanah dan pupuk organik 2-2. Persemaian benih dilakukan dengan cara di tebar setelah tebar tutup tanah diatas benih dan penyiraman air pake kaleng gembor, pecah lembaga kurang lebih 8 hari dan persemaian selama dua minggu. Benih tanaman sawi hijau unggul bentuknya bulat kecil berwarna coklat atau kehitam-hitaman (Rukmana), 2013)

\section{Penyiapan Lahan}

Lahan dipersiapkan dengan cara 4 grobak tanah tempat penyiapanlahan selanjutnya dibuat dalam bentuk polybagukuran 30-30 mpertama tanah dan pupuk organik dihaluskan kemudian dibiarkan selamasatuminggu tujuan tanah dibiarkan selama satu minggu agar terkena sinar matahari secara langsung dan sekaligus dapat mencegah tumbuhnya hamaatau patogen lalu isi tanah memakai sendok nasi didalam polybag tersebut. Perbedaan antara teori dan di lapang adalah menurut. Rukmana (1994) jarak tanam yang ideal untuk tanaman sawi hijau yaitu 50x60 cm tetapi yang menggunakan di lapang yaitu $25 \times 25 \mathrm{~cm}$. 


\section{Penanaman}

Penanaman yang dilakukan dengan cara transplanting mencabut bibit dari tempat persemaian dan dilakukan penanaman secara langsung di polybag ukuran 30-30 yang telah dipersiapkan terlebih dahulu berdampak terhadap pertumbuhan tanaman sawi hijau yang tidak merata.

Jarak tanam yang digunakan yaitu $25 \mathrm{x} 25 \mathrm{~cm}$ jarak tanam yang demikian termasuk kategori rapat. MenurutRukmana (1994) jarak tanam yang ideal untuk tanaman sawi hijau yaitu $50 x 60 \mathrm{~cm}$.

Menurut Sintompul dan Guritno (1995), hasil setiap individu tanaman yang diperoleh lebih sedikit jika kepadatan populasi lebih tinggi dan tanaman tidak dapat tumbuh jika kepadatan terlalu tinggi. Oleh karena itu diperoleh hasil yang tinggi perlu diadakan kepadatan tanaman yang dianggap layak.

Pada kepadatan tanah yang optimal, masih terjadi kompotisi antara tanaman yang dapat menyebabkan pertumbuhan dan hasil tanaman per individu berkurang, namun karena jumlah tanaman 10 polybag sehingga produksi masih dapat meningkat (Sugito, 1994). Sedangkan menurut suryato (1990), pengaturan baik tata letak maupun pengaturan populasi dapat mengetahui variasi naungan yang terbentukseperti tinggi tanaman; indeks luas daun, dapat menyebabkankerebaan tanaman.

\section{Pemeliharaan}

Pemeliharan tanaman selama pelaksanaan praktek kerja lapang meliputipenyiraman, penyiangan, pemupukan; dan pengendalian hama dan penyakit.

\section{Pemupukan}

Pemupukan yang digunakan yaitu pupuk organik sebelum tanam sawi hijau tanah campuran dengan pupuk kandang selain itu pemberian pupuk yang bersentuhan langsung dengan akar tanaman dapat menyebabkan kematian pada tanaman maka itu kedua kali tidak dikasih pupuk karena umur tanaman sawi hijau 30-40 hari. Sebelum menanam sudah diberi pupuk kandang, kompos, jerami padi, tanah maka itu pada saat pertumbuhan tanaman tidak memberi pupuk lagi karena mengandung unsur nitrogen $(\mathrm{N})$ organik.

\section{Penyiraman}

Penyiraman ini tergantung pada musimnya, bila musim hujan dirasa sudah berlebih, maka perlu melakukan pengurangan air yang ada tetapi sebaliknya bila musim kemarau tiba harus memperhatikan keperluhan air terhadap tanaman sawi hijau yang kita tanam. Penyiramandilakukan sehari sekali pada sore hari awal tanam sampai panen. karena umur tanaman 30-40hari 


\section{Pengendalian Hama dan Penyakit}

1. secara manual yaitu mencabut rumput dengan tangan yang tumbuh di tanaman itu sendiri dan lain-lain

2. secara kimia yaitu obat-obatan contoh herbisida dan lain-lain Pengendalian hama yang dilakukan secara prefentif yaitu dengan cara membunuh hama secara langsung dan mencabut tanaman yang terserang penyakit.

\section{Pemanenan}

Panen ada 2 cara yaitu mencabut seluruh tanaman beserta akarnya dengan memotong bagian pangkal batang yang berada di atas tanah. Umur panen sawi hijau 30-40 hari setelah tanam, sebaiknya terlebih dahulu dilihat fisik tanaman seperti warna bentuk dan ukuran daun.

Tanaman yang baru dipanen, ditempatkan di tempat yang teduh agar tidak cepat laju dengan cara diperciki air. Selanjutnya lakukan sortasi untuk memisahkan bagian tanaman bagian tanaman yang tua, busuk atau sakit. Penyimpanan bisa menggunakan wadah berupa keranjang bambu, wadah plastik, atau karton, yang berlubang -lubang untuk menjaga sirkulasi udara (anonymous,2009). Pemanenan dilakukan pada saat tanaman berumur 30-40 hari setelah tanam. Pemanenan sawi hijau dilakukan pada masa bunga mencapai ukuran maksimal dan telah padat tetapi cukup bunganya belum mekar.

\section{KESIMPULAN}

Sawi hijau dapat tumbuh dengan baik apabila yang menjadi syarat tumbuhnya terpenuhi. Pertumbuhan tanaman sawi hijau, pengaruhi oleh faktor agar produksi yang diharapkan, dapat tercapai. Faktor-faktor tersebut antara lain: penggunaan benih/bibit unggul, pengolahan tanah, pengairan, pemupukan, dan pengendalian hama dan penyakit.

\section{REFERENCES}

Anom, Edison. 2008. Efek Pemberian Tricho-Kompos Jeram Padi Terhadap Pertumbuhan dan Produksi sawi Hijau (Brassica juncea L). SAGU Vol. 7 No. 2: Hal. 7-12.

Anonymous, 2007. Budidaya sawi dalamhttp://id.search.yahoo.com/search.

Anonymous, 2009. Budidaya sawi semi organik dalam http//jambi.Litbang.deptan.go.id.balai pengkajian teknologi pertanian. Jambi.

Ali, M. (2015). PENGARUH DOSIS PEMUPUKAN NPK TERHADAP PRODUKSI DAN KANDUNGAN CAPSAICIN PADA BUAH TANAMAN CABE RAWIT (Capsicum frutescens L.). JURNAL AGROSAINS: KARYA KREATIF DAN INOVATIF, 2(2), 171178.

Hariyadi, B. W., Ali, M., \& Nurlina, N. (2017). Damage Status Assessment Of Agricultural Land As A Result Of Biomass Production In Probolinggo Regency East Java. ADRI International Journal Of Agriculture, 1(1). 